\title{
The Implication of Employing Magnetic Test Kit on Students' Interest, Teachers' Teaching Method and Students' Visualization Ability
}

\author{
Mohd Erfy Ismail ${ }^{1, *}$, Faizal Amin Nur Yunus ${ }^{1}$, Junita Sulaiman ${ }^{1}$, Norfarah Nordin², \\ Nadzrah Sa'adan ${ }^{3}$ \\ ${ }^{1}$ Faculty of Technical and Vocational Education, Universiti Tun Hussein Onn Malaysia, Malaysia \\ ${ }^{2}$ Graduate School of Business, Universiti Sains Malaysia, Malaysia \\ ${ }^{3}$ Academy of Language Studies, Universiti Teknologi MARA Cawangan Johor, Kampus Pasir Gudang, Malaysia
}

Received May 4, 2020; Revised July 4, 2020; Accepted July 20, 2020

\section{Cite This Paper in the following Citation Styles}

(a): [1] Mohd Erfy Ismail, Faizal Amin Nur Yunus, Junita Sulaiman, Norfarah Nordin, Nadzrah Sa'adan , "The Implication of Employing Magnetic Test Kit on Students' Interest, Teachers' Teaching Method and Students' Visualization Ability," Universal Journal of Educational Research, Vol. 8, No. 9, pp. 3858 - 3863, 2020. DOI: 10.13189/ujer.2020.080909.

(b): Mohd Erfy Ismail, Faizal Amin Nur Yunus, Junita Sulaiman, Norfarah Nordin, Nadzrah Sa'adan (2020). The Implication of Employing Magnetic Test Kit on Students' Interest, Teachers' Teaching Method and Students' Visualization Ability. Universal Journal of Educational Research, 8(9), 3858 - 3863. DOI: 10.13189/ujer.2020.080909.

Copyright $\subseteq 2020$ by authors, all rights reserved. Authors agree that this article remains permanently open access under the terms of the Creative Commons Attribution License 4.0 International License

\begin{abstract}
Education is an ongoing process and is constantly accepting changes and improvement in line with the needs and wants of the community. The 21st - century world is seeing the use of multimedia and information technology monopolizing the lives of the general public with the motto of a borderless world. One of the most popular developments today is Augmented Reality (AR) technology that uses barcode scanners as a medium for learning. This study aims to find out students' interest in learning, teachers' teaching method, and students' visualization ability in welding technology subjects. The quantitative study through a survey method was used in this study. The study population involved 105 welding technology students of Batu Pahat Vocational College. The purposive sampling consists of 30 respondents of 3rd-year students who are taking the Non-Destructive Test (NDT) welding subject under the topic of magnetic particle test. The instrument used was a questionnaire. Data were collected and analyzed descriptively. The finding shows that the Cronbach Alpha value is 0.73 which indicates that the instrument's reliability is high. The results of this study found that by using magnetic particle test teaching kits can increase students' interest in learning $(M=4.76)$, positively affect the teachers' teaching method ( $\mathrm{M}=4.72)$, and helped
\end{abstract}

to enhance students' visualization ability ( $\mathrm{M}=4.80$ ). Thus, the findings indicate that the use of this teaching kit improves the teaching and learning process either in the classroom or in the workshop.

Keywords Learning Magnetic Test, Student Interest, Teacher Teaching Method and Student Visualization

\section{Introduction}

Technical and Vocational Education plays a challenging role today and this is due to the development of the current wave of transformation. This TVET field has a great responsibility to realize the various educational transformation policies set by the Ministry of Education (MOE) to raise the quality of human capital. Technical and Vocational Education and Training (TVET) is often misunderstood by students as the last choice in their pursuits. This may be due to the previous education system which emphasized that the academic achievement system is better than enhancing the individual's potential and value[1]. According to [2], TVET is an educational system 
that provides specialized training for technical skills and several other skills.

The welding courses in TVET are not foreign courses. This is because welding has been around for a long time before the transformation of technical school to vocational college. The welding field is widely being learned throughout the world including our country. The welding process is to weld metal or steel such as car body, building frame, boiler, and boat's body. Examples of welding processes used in vocational colleges include manual arc welding, Metal Inert Gas Welding (MIG), Oxygen Oxidation Welding, and Tungsten Inert Gas (TIG) and Arc Welding. Various methods are used for teaching and learning (T\&L) in vocational colleges to enhance the process of acquiring knowledge for students. According to [3] to enhance T\&L information delivery is not limited to commonly used tools such as blackboards, pictures, and even teaching materials are included in all kinds of hardware and software for teaching.

The latest technology most widely used by most of the students is the smartphone. Learning by using mobile phones in education is called Mobile Learning (M-learning). M-learning can provide a more flexible approach as it gives students a whole new dimension. With this M-learning, learning can take place anywhere and is not subjected to the classroom only as the use of M-learning is unlimited. Besides, M-learning also enables students to leverage the power of advanced technology by using a variety of uploaded learning resources. For example, in the latest education students can use Augmented Reality technology to assist them in understanding the content of their learning.

Augmented Reality (AR) is a state that combines real-world and virtual and interactive with reality and is a 3-dimensional animation [4]. A body or life that seems to live in the real world of humans can be created using new technology where it combines one-dimensional, two-dimensional (2D) or three-dimensional (3D) into it to produce AR. According to [5], AR is a technology that combines 2-dimensional or 3-dimensional virtual objects into a 3-dimensional real-world connection and applies them to the real world. New possibilities in the T\&L process provided by AR are increasingly being recognized by researchers in the education field. According to [6], the existence of virtual objects and real-world environments enables students to visualize complex space relationships with real-world experience phenomena, interacting with 2D and 3D in mixed reality [7].

\section{Materials and Methods}

The methods of approach and presentation that teachers use when teaching a topic are sometimes tedious and of little interest to the student because it is difficult for the students to understand. This problem is due to the traditional teaching methods and techniques used by the teacher that does not fit the students' minds. According to [8], the failure of teachers who maintain traditional methods without making changes through methods and techniques guided by current technological changes is a challenge that must be addressed and resolved immediately. According to [9], the issue is that students are not able to master the knowledge conveyed by the teacher and thus the teacher's T\&L objectives are not being met

In addition, students are also less interested in the style of presentation given by the teachers who are still maintaining the traditional learning style. Students find it difficult to concentrate and be interested in engaging in classroom teaching and learning activities, especially learning that involves teacher-centered methods [10]. Students' interests and attitudes greatly influence the success of a learning objective. According to [11], students' interest in teaching and learning is characterized by learning that has practical methods, graphics, drawing, and moving objects. Therefore, one of the efforts that can attract students is that teachers should strive and innovate to find attractive ways in the learning process so that students' interests and motivations can be nurtured [12].

Application-based teaching and learning methods can be of interest to students as well as animations, drawings and simulations that generate greater interest for students to learn [13]. Teacher teaching skills that practice a variety of applications and strategies facilitate students to better understand and promote student learning and teachers will also have a deeper knowledge to assist students in learning [14]. Therefore, teachers should take the opportunity to use new technologies and applications in the T\&L process to attract students and at the same time facilitate the process of acquiring knowledge for students.

According to [15], teacher-centered learning will have an impact on students who will only receive information delivered by their teachers and will be less aware of the content of the learning subject. This can be seen as a problem for students who are unable to master the subject due to inaccurate teaching methods applied. Most teacher-centered teaching and learning will make the students weak in visualizing. An example of visualization is like a realistic view in either 2D or 3D. According to [16], visualization presents data in a specific way to make things clearer by involving the human sensory system and the key to visualization is information that can be gathered and interpreted directly to the input.

According to a study by [17], visualization is a form of information transmission used to describe animations, drawings, or diagrams that can be explored, calculated, and analyzed data. Visualization is also a person's ability to interpret a particular purpose into a form of information or a comprehensible picture. Thus, teaching using AR-assisted teaching kits can help interpret visuals involving the process of magnetic particle testing. Students will find it easier to understand when visual processes are 
presented in real life.

Thus, a descriptive quantitative study through a survey was conducted at Batu Pahat Vocational College in Johor, Malaysia. The results of the study were analyzed descriptively to describe the findings. A questionnaire was used as a research instrument to examine the implications of incorporating the teaching kit on students' interest, teachers' teaching method, and students' visualization ability in the context of learning.

\subsection{Sample of the Study}

The population of the study involved 105 students of the Welding Technology Programme of Batu Pahat Vocational College. The sampling method used was a purposive sampling focusing on 30 students of the third-year students of the Welding Technology Programme.

\subsection{Instrument of the Study}

The instrument used in this study was a questionnaire. The questionnaire consists of 3 parts which are Part A, B, and $C$. The researchers used average mean gathered from the descriptive statistic. Meanwhile, Part A, Part B, and Part C comprise the items related to respondents' interest, teachers' teaching method, and students' visualization ability while learning using the magnetic particle test kit. The reliability test was conducted to test the questionnaire's reliability. The result of the Alpha Cronbach value of 0.73 shows the items in the questionnaire are high in reliability.

\section{Results}

All items included in the questionnaire were analyzed using the 5-point Likert scale; strongly disagree, disagree, uncertainty, agree, and strongly agree. Table 1 shows the interpretation scale of the means of this study based on previous studies [18].

Table 1. Mean Scores Interpretation

\begin{tabular}{|c|c|}
\hline Mean Score Range & Interpretation \\
\hline $1.00-2.33$ & Low \\
\hline $2.34-3.67$ & Medium \\
\hline $3.68-5.00$ & High \\
\hline
\end{tabular}

The results from Part $\mathrm{A}, \mathrm{B}$, and $\mathrm{C}$ are shown in the mean and standard deviation table. The average mean score is used to indicate the respondents' interest in the learning process, teaching method, and students' visualization ability.

\subsection{Expert Confirmation}

The features of the kit learning model have been constructed based on recommendations made by the field experts referred. The researchers have implemented the project design method and carried out the initial draft of the project. The analysis given by the experts which involved two welding experts and one instructor from KV Wakaf Tembusu is as shown in Table 2.

Table 2. Expert Analysis

\begin{tabular}{|c|l|c|c|c|}
\hline NO & \multicolumn{1}{|c|}{ ITEM } & \multicolumn{3}{|c|}{ EXPERT } \\
\hline 1 & \multicolumn{1}{|c|}{ Good strength? } & $\sqrt{ }$ & $\sqrt{ }$ & $\sqrt{ }$ \\
\hline 2 & $\begin{array}{l}\text { Does the teaching kit have an } \\
\text { interesting design? }\end{array}$ & $\sqrt{ }$ & $\sqrt{ }$ & $\sqrt{ }$ \\
\hline 3 & $\begin{array}{l}\text { Does this teaching kit have a } \\
\text { user-friendly design? }\end{array}$ & $\sqrt{ }$ & $\sqrt{ }$ \\
\hline 4 & $\begin{array}{l}\text { Is this teaching kit easy to operate } \\
\text { based on its design? }\end{array}$ & $\sqrt{ }$ & $\sqrt{ }$ & $\sqrt{ }$ \\
\hline 5 & $\begin{array}{l}\text { Does the design of this lesson kit meet } \\
\text { safety features when used? }\end{array}$ & $\sqrt{ }$ & $\sqrt{ }$ & $\sqrt{ }$ \\
\hline
\end{tabular}

The checklist shows that the experts involved agreed that the design features of this type of magnetic particle test kit meet the desired characteristics of a good teaching aid requirement.

Table 3. Mean values of students' interest items

\begin{tabular}{|c|l|c|c|}
\hline No & \multicolumn{1}{|c|}{ Item } & Mean & $\begin{array}{c}\text { Standard } \\
\text { Deviation }\end{array}$ \\
\hline A1 & $\begin{array}{l}\text { I like to ask my teachers during the } \\
\text { magnetic learning process using } \\
\text { the AR application }\end{array}$ & 4.43 & 0.50 \\
\hline A2 & $\begin{array}{l}\text { I can use the AR application } \\
\text { beyond my study time }\end{array}$ & 4.69 & 0.67 \\
\hline A3 & $\begin{array}{l}\text { I enjoy the magnetic learning } \\
\text { process by using the AR } \\
\text { application. }\end{array}$ & 4.76 & 0.43 \\
\hline A4 & $\begin{array}{l}\text { I think teachers teaching styles } \\
\text { boost my interest in learning by } \\
\text { using AR applications. }\end{array}$ & 4.86 & 0.34 \\
\hline A5 & $\begin{array}{l}\text { I am interested in using AR } \\
\text { application systems in magnetic } \\
\text { learning. }\end{array}$ & 4.93 & 0.25 \\
\hline A6 & $\begin{array}{l}\text { I am excited to get a high score } \\
\text { during the quiz }\end{array}$ & 4.96 & 0.18 \\
\hline
\end{tabular}

Based on Table 3, it is found that most students responded positively towards the teaching kit application in capturing the students' interest in learning. Table 3 shows the analysis of the respondents' results on items A1 to A6 and the results of the survey show that all items are at a high level ( $\mathrm{M}>3.68$ and above). Based on the mean scores obtained, respondents agreed that this magnetic teaching kit could enhance their interest in learning. 
Table 4. Mean values of the teachers' teaching method items

\begin{tabular}{|l|c|l|c|}
\hline No & Item & Mean & Standard Deviation \\
\hline B1 & Teachers have given me many opportunities to ask questions with the help of AR applications & 4.53 & 0.51 \\
\hline B2 & I can easily understand the topics that teachers teach using the AR application & 4.63 & 0.49 \\
\hline B3 & In teaching, teachers give all students a fair amount of attention & 4.73 & 0.45 \\
\hline B4 & The teaching teacher managed to catch my attention using the AR application & 4.80 & 0.41 \\
\hline B5 & Teachers can provide a clear picture of a topic being taught by using AR applications & 4.80 & 0.41 \\
\hline B6 & The teaching methods used by teachers are interesting when using the AR application. & 4.86 & 0.35 \\
\hline
\end{tabular}

Table 5. Mean values of the students' visualization ability items

\begin{tabular}{|c|l|c|c|}
\hline No & \multicolumn{1}{|c|}{ Item } & Mean & Standard Deviation \\
\hline C1 & $\begin{array}{l}\text { I can understand the concept of magnetism through visualization by } \\
\text { using AR applications }\end{array}$ & 4.73 & 0.45 \\
\hline C2 & $\begin{array}{l}\text { I can improve my visualization skills better when using AR } \\
\text { applications }\end{array}$ & 4.76 & 0.43 \\
\hline C3 & $\begin{array}{l}\text { I can visualize the shape of components by visualizing it through an } \\
\text { AR application }\end{array}$ & 4.76 & 0.43 \\
\hline C4 & $\begin{array}{l}\text { I can engage directly in learning through visualization in AR } \\
\text { applications }\end{array}$ & 4.83 & 0.38 \\
\hline C5 & $\begin{array}{l}\text { I can see the image through the visualization that is displayed when } \\
\text { using the AR application }\end{array}$ & 4.86 & 0.35 \\
\hline C6 & I can increase the visualization power with the video views shown & 4.86 & 0.35 \\
\hline
\end{tabular}

Based on Table 4 it is found that most respondents agreed that this teaching kit can help in the teaching and learning process. Table 4 shows the analysis of the respondents' feedback on items B1 to B6 and the results of the survey show that all items are at a high level ( $\mathrm{M}>$ 3.68 and above). Based on the mean scores obtained, respondents agreed that this magnetic teaching kit enhanced their teachers' teaching method.

Table 5 shows the analysis of the respondents' results according to items $\mathrm{C} 1$ to C6. The results show that all items are at a high level $(\mathrm{M}>3.68$ and above). Most of the students strongly agreed with the items that indicated that the usage of this magnetic particle test teaching kit could assist them in improving their visualization ability.

\section{Discussion}

Based on the research conducted, the researchers believe that the use of this teaching kit should be incorporated into the teaching and learning process as it benefited both parties; students and teachers. According to [19], who stated that students are more interested to learn other than the traditional method of learning. With this instructional kit, students will be more focused on multimedia software such as sound, acoustics, animations, diagrams, and colorful pictures that will enhance students' cognitive, interest, psychomotor, and behavioral achievement [20].

Also, the use of a teaching kit can provide a clear picture of a learning concept being studied and can enhance students' understanding and interest. According to [21], the main purpose of the instructional kit is to create students 'enjoyment of learning a subject while at the same time fostering students' love towards the subject. When a student is interested in a subject, they will work hard to study to attain the best score in the [22].

In terms of teaching methods, educators are individuals who play important roles in producing outstanding and high-quality students. According to [23], the use of digital resources enables students to actively engage in cognitive and emotional processes. Teachers need to be smart in identifying students' ability to accept the lessons delivered [24]. In the context of teaching and learning welding subjects, teachers need to be more creative in planning their teaching methods. According to [25], teachers need to actively engage students in their teaching and learning process and this requires high teaching skills among teachers.

Creative teachers are educators who can structure learning experiences that allow the development of creativity among their students. According to [26], creative teachers can demonstrate the flexibility in applying teaching approaches and teaching strategies in their role. With flexibility, it will be easier for students to accept, understand, and appreciate the facts they are learning [27].

In terms of teaching methods, teachers should prepare the teaching in stages and make sure it suits the students' level so that the students can easily understand the content of his or her learning. According to [28], learning is a process developed by teachers to develop thinking creativity that enhances the ability to create new perspectives to enhance mastery of learning.

In terms of student visualization, this instructional kit is developed using multimedia technology that helps 
students improve their visualization and imagination in the teaching and learning process. According [29], visualization is an important skill in students' development in the T\&L process. Visualization skills make teaching and learning processes fun and enjoyable for students [30].

In addition, according to [31], the features of teaching kits such as animation, video, sound, text, audio and graphics can stimulate students' thinking and make a significant impact on their learning. The use of electronic or multimedia ABBMs such as audiovisuals, computers, and software has been getting attention as it has been of great interest to students [32]. Therefore, the use of Augmented Reality (AR) is best used as an ABBM development platform that requires student visualization. According to [33]. AR technology can be used in other subject-based learning to provide a variety of learning methods and facilitate the understanding of the user's visualization and the ability to motivate students. Effort should be made by relevant parties on the use of developmental learning material as an educational platform. It is important for teaching aids to be able to provide the feeling of a one on one interaction thus help coach the students with below-average performance.

\section{Conclusions}

Generally, students' interest, teaching method, and students' visualization ability were recorded at a high level on the use of the Learning Magnetic Test for learning. Additionally, students also have a high level of interest in using the Learning Magnetic Test for learning. The positive result of this study suggests that Learning Magnetic Test can be utilized to achieve the learning outcomes for any courses, especially in higher education level. No issue on the students' interest, teaching method, and students' visualization ability raised by these groups of teachers and students, therefore, more activities should be blended into the learning process and hope for a positive effect on the learning process for future research await.

Instructors or teachers should be able in applying the right methods and strategies in teaching and learning whether in conducting a class or in online learning. Thus, literacy-related courses using the Learning Magnetic Test needs to be carried out to improve the literacy of educators on the proper ways to handle it. Learners should also be exposed to information on the usage of the Learning Magnetic Test Kit as they will be the ones who are at a loss if they were left behind and failed to catch up with the learning. Students also should have been given information on ways to properly use this product. Students need to be guided in using the Learning Magnetic Test Kit as an initial effort to avoid problems during the teaching and learning process.

To ensure implementation of the course development using the Learning Magnetic Test is achieved, educational institutions should standardize the use of this product for each topic or subject so that it can be fully utilized in teaching and learning in this age-advanced technology era. This is because the Learning Magnetic Test Kit does not only have a positive impact on the students, but it also affects the instructors or teachers by improving the teachers' teaching performance and diversifying the teaching methods thus affecting the academic achievement of students positively.

\section{Acknowledgement}

We would like to thank the experts who participated in this study and also thank to the Universiti Tun Hussein Onn Malaysia for the financial support under the Research Fund Vot. E15501 from the Research Management Center (RMC) Universiti Tun Hussein Onn Malaysia (UTHM).

\section{REFERENCES}

[1] Ahmad, M. J., Jalani, N. H., Hasmori, A. A., \& dan Vokasional, F. P. T. (2015). TVET di Malaysia Cabaran dan Harapan. In Seminar Majlis Dekan-Dekan Pendidikan Awam 2015 (p. 340).

[2] Kayan, I. C., Hamzah, R., \& Udin, A.(2014) Transformasi Pendidikan Teknik dan Vokasional: Membentuk Pemimpin Masa Depan

[3] Halim, A., Hanim, H., \& Lai, C. S. (2012). Penilaian keberkesanan kit pengajaran transistor bagi aliran vokasional.

[4] Pramono, A. (2017). Media Pendukung Pembelajaran Rumah Adat Indonesia

[5] Dhiyatmika, I. D. G. W., Putra, I. K. G. D., \& Mandenni, N. M. I. M. (2015). Aplikasi Augmented Reality Magic Book Pengenalan Binatang untuk Siswa TK. Lontar Komputer: Jurnal Ilmiah Teknologi Informasi, 120-127

[6] Dunleavy, M., \& Dede, C. (2014). Augmented reality teaching and learning. In Handbook of research on educational communications and technology (pp. 735-745). Springer.

[7] Ichsan, M. (2016). Psikologi Pendidikan dan Ilmu Mengajar. JURNAL EDUKASI: Jurnal Bimbingan Konseling, 2(1), 60-76.

[8] Hussin, N. (2017). Penggunaan laman web sebagai transformasi dalam pengajaran dan pembelajaran pendidikan Islam. O-JIE: Online Journal of Islamic Education,1(2).

[9] Mohd Noor, S. (2016). Keberkesanan bahan bantu mengajar VATA dalam menangani miskonsepsi dan meningkatkan kefahaman konsep abstrak sains sekolah rendah (Doctoral dissertation, Universiti Pendidikan Sultan Idris) 
[10] Tamami, R. (2014). Pemanfaatan Media Pembelajaran interaktif (MPI) PowerPoint untuk Visualisasi Konsep Menggambar Grafik Persamaan Garis Lurus. Jurnal Online

[11] Horax, M., Santoso, L. W., \& Gunadi, K. (2017). Media Interaktif Tentang Bahaya Merokok Bagi Pelajar. Jurnal Infra, 5(1), 310-314

[12] Hassan, H. (2012). Kesan penggunaan digital electronics kit terhadap pencapaian pelajar yang berbeza gaya kognitif (Doctoral dissertation, Universiti Tun Hussein Onn Malaysia).

[13] In'am, A., Saad, N., \& Ghani, S. (2012). A Metacognitive Approach to Solving Algebra Problems.

[14] Tamami, R. (2014). Pemanfaatan Media Pembelajaran interaktif (MPI) PowerPoint untuk Visualisasi Konsep Menggambar Grafik Persamaan Garis

[15] Hayadi, B. H. (2017). Visualisasi Konsep Umum Sistem Pakar Berbasis Multimedia. Riau Journal of Computer Science, 3(1), 17-22.

[16] Ahmad, S. F., \& Tamuri, A. H. (2010). Persepsi guru terhadap penggunaan bahan bantu mengajar berasaskan teknologi multimedia dalam pengajaran j-QAF. Journal of Islamic and Arabic Education, 2(2), 53-64

[17] Ngasiman, N. (2014). Kesan kaedah pembelajaran koperatif terhadap pencapaian pelajar dalam mata pelajaran matematik (Doctoral dissertation, Universiti Tun Hussein Onn Malaysia).

[18] Cooper, D. (2016). The Effectiveness of Instructional Video in the Acquisition of Cognitive, Affective and Psychomotor Skills in Practical Sports Therapy Rehabilitation (Doctoral dissertation, Durham University).

[19] Azman, M. N. A., Azli, N. A., Mustapha, R., Balakrishnan, B., \& Isa, N. K. M. (2014). Penggunaan alat bantu mengajar ke atas guru pelatih bagi topik kerja kayu, paip dan logam. Sains Humanika, 3(1).

[20] Safien, A. B., \& Syuharul, N. (2014). Kajian terhadap perbezaan pencapaian SPM pelajar lelaki dengan pelajar perempuan dan faktor yang mempengaruhinya.

[21] Ahmad, A., \& Jinggan, N. (2017). Pengaruh kompetensi kemahiran guru dalam pengajaran terhadap pencapaian akademik pelajar dalam mata pelajaran Sejarah. JuKu: Jurnal Kurikulum \& Pengajaran Asia Pasifik, 3(2), 1-11

[22] Daud, N. B. M., Ahmad, A. R., \& Yakub, N. M. (2016, January). Pembelajaran Berteraskan Kemahiran Berfikir
Aras Tinggi (KBAT) Di Dalam Pengajaran Dan Pembelajaran Mata Pelajaran Sejarah. In Proceeding on Regional Education (Vol. 1, pp. 352-360).

[23] Roehl, A., Reddy, S. L., \& Shannon, G. J. (2013). The flipped classroom: An opportunity to engage millennial students through active learning strategies. Journal of Family

[24] Nugroho, B. W. (2016, December). Tuntutan Profesi Guru Penjas Antara Harapan Kenyataan Dalam Menghadapi Era Persaingan Bebas (GLOBAL).

[25] Chong, O. S., Mahamod, Z., \& Hamzah, M. I. M. (2017). MENEROKA KAEDAH PENGAJARAN GURU CEMERLANG BAHASA MELAYU NEGERI SARAWAK: SATU KAJIAN KES (Exploring Teaching Methods of Sarawak Malay LanguageExcellent Teacher: A Case Study). Jurnal Pendidikan Bahasa Melayu, 7(1), 93-108.

[26] Rahayu, G. D. S., \& Firmansyah, D. (2019). Pengembangan pembelajaran inovatif berbasis pendampingan bagi guru sekolah dasar. Abdimas Siliwangi, 1(1), 17-25.

[27] Ariffin, A. (2015). Kesan persembahan masalah berbentuk grafik dan animasi bagi pembelajaran berasaskan masalah dalam talian kursus lukisan kejuruteraan (Doctoral dissertation, Universiti Sains Malaysia).

[28] Jamian, A. R., \& Ismail, H. (2016). Pelaksanaan pembelajaran menyeronokkan dalam pengajaran dan pembelajaran bahasa melayu. Jurnal Pendidikan Bahasa Melayu, 3(2), 49-63.

[29] Sutaji, S. S. (2015). Kesan penggunaan koswer multimedia animasi visual terhadap pencapaian pelajar dalam mata pelajaran matematik (Doctoral dissertation, Universiti Tun Hussein Onn Malaysia).

[30] Azman, M. N. A., Azli, N. A., Mustapha, R., Balakrishnan, B., \& Isa, N. K. M. (2014). Penggunaan alat bantu mengajar ke atas guru pelatih bagi topik kerja kayu, paip dan logam. Sains Humanika, 3(1).

[31] Wardani, S. (2015). Pemanfaatan Teknologi Augmented Reality (AR) untuk Pengenalan Aksara Jawa pada Anak. Jurnal Dinamika Informatika, 5(1).

[32] Hashim, S., Al Jafri, N. A., Ismail, M. E., Rahman, K. A. A., Masek, A., \& Ismail, A. (2019, August). Students' Literacy, Readiness and Awareness in using Edmodo for Learning. In 2019 IEEE 10th Control and System Graduate Research Colloquium (ICSGRC) (pp. 231-235). IEEE. 